\title{
PROFIL PENDERITA PSORIASIS DI POLI KULIT DAN KELAMIN RSUD MEURAXA KOTA BANDA ACEH PERIODE TAHUN 2016-2019
}

\author{
Ulfa Rizqia1, Rizky Kurniawan², Elfa Wardani Fitri ${ }^{3}$ \\ ${ }^{1}$ Program Studi Kedokteran, Fakultas Kedokteran, Universitas Abulyatama \\ ${ }^{2}$ Dosen Program Studi Pendidikan Dokter
}

[email korespondensi:ulfarizqiahs@gmail.com]

\begin{abstract}
Profile of Psoriasis Patients at Dermatology and Venereology Polyclinic of Meuraxa Hospital of Banda Aceh Since 2016-2019. Psoriasis is chronic inflammatory diseases of skin with a strong genetic basis characterized by changes in growth and differentiation of epidermal cells with vascular manifestations, and also suspected the influence of the nervous system. This research aims to find out the profile of patients with psoriasis at the Dermatology and Venereology Polyclinic of Meuraxa Hospital Banda Aceh City Since 2016 - 2019. This research uses descriptive method retrospectively and samples were taken using the total sampling method. The research result showed there were 82 cases of psoriasis. Based on age, the most common in the age of 26-35 years old are 20 cases consisted of 8 men and 12 women. Based on the sex, the most common cases occurred in women are 45 cases, and based on the type, psoriasis vulgaris was the most common with 68 cases. The conclusion of this research is the age group most experienced psoriasis are 26-35 years old that often attacks women more than men and the psoriasis vulgaris is the most common type found.
\end{abstract}

Keywords: Psoriasis, Age, Sex, Psoriasis Type.

Abstrak: Profil Penderita Psoriasis di Poli Kulit dan Kelamin RSUD Meuraxa Kota Banda Aceh Periode Tahun 2016-2019. Psoriasis adalah penyakit peradangan kulit kronik dengan dasar genetik yang kuat dengan karakteristik perubahan pertumbuhan dan diferensiasi sel epidermis disertai manifestasi vaskuler, dan juga diduga adanya pengaruh dari sistem saraf. Penelitian ini bertujuan untuk mengetahui profil penderita psoriasis di Poli Kulit dan Kelamin RSUD Meuraxa Kota Banda Aceh Periode Tahun 2016 - 2019. Penelitian ini menggunakan metode penelitian deskriptif yang dilakukan secara retrospektif dan sampel diambil dengan menggunakan metode total sampling. Pada hasil penelitian ini terdapat 82 kasus psoriasis. Berdasarkan usia, paling banyak terjadi pada usia 26-35 tahun yaitu sebanyak 20 kasus terdiri dari 8 laki-laki dan 12 perempuan. Berdasarkan jenis kelamin, paling banyak terjadi pada perempuan sebanyak 45 kasus, dan berdasarkan tipe psoriasis paling banyak terjadi adalah tipe psoriasis vulgaris yaitu sebanyak 68 kasus. Kesimpulan pada penelitian ini kelompok usia yang paling banyak mengalami psoriasis yaitu usia 26-35 tahun, lebih sering menyerang perempuan dibandingkan laki-laki dan tipe psoriasis vulgaris adalah yang paling banyak ditemukan.

Kata Kunci : Psoriasis, Usia, Jenis Kelamin, Tipe Psoriasis

\section{PENDAHULUAN}

Kulit merupakan bagian terluar tubuh yang mempunyai luas sekitar 2 $\mathrm{m}^{2}$ dan menjadi benteng pertahanan pertama apabila datang ancaman dari luar tubuh. Kulit adalah organ tubuh terbesar di dalam tubuh manusia yang memiliki fungsi untuk melapisi otot, tulang ,organ-organ dan semua bagian tubuh yang ada di dalamnya, maka 
kesehatan kulit merupakan salah satu kesehatan yang perlu di jaga. Kesehatan kulit sangat penting bagi manusia, namun saat ini masih banyak masyarakat yang sering mengabaikan kesehatan kulit karena masih banyak masyarakat yang menganggap remeh tentang penyakit kulit. Penyakit kulit merupakan salah satu penyakit yang dominan terjadi terutama bagi kesehatan masyarakat Indonesia, yang disebabkan oleh beberapa penyebab seperti bakteri, virus, jamur, parasit atau bahkan reaksi dari alergi. Salah satu penyakit kulit adalah psoriasis.

Psoriasis adalah penyakit inflamasi kulit yang termasuk dalam kelompok dermatosis eritroskuamosa, yang ditandai dengan adanya plak berwarna merah ditutupi oleh sisik tebal berwarna putih keperakan. Penyakit ni bersifat kronis residif dan dapat dialami oleh berbagai usia. Penyebab dari psoriasis masih belum diketahui secara pasti, namun ada beberapa faktor yang menjadi timbulnya psoriasis ini, yaitu faktor lingkungan, imunologik, dan faktor genetik.

Menurut National Institutes of Health (NIH), diperkirakan sekitar 2,2\% penduduk Amerika Serikat yang mengalami penyakit psoriasis. Penelitian lain yang dilakukan terhadap kasus penyakit ini adalah 26.000 penduduk suku Indian Amerika Selatan, namun penelitian ini tidak berhasil mengungkapkan satu pun kasus psoriasis. Sedangkan menurut World Health Organization (WHO), diperkirakan $3 \%$ penduduk dunia menderita psoriasis dengan perbandingan 1:1 pada pria dan wanita.

Psoriasis terjadi pada pria dan wanita dari segala kelompok usia, suku, dan berbagai negara. Angka kejadian psoriasis juga tergantung pada iklim dan faktor genetik dari setiap populasi. Prevalensi psoriasis di negara yang mempunyai iklim tropis dan penduduk berkulit gelap seperti penduduk Afrika umumnya angka penyakit psoriasis ini lebih rendah yaitu sebesar 1,3\% dibandingkan $2,5 \%$ pada penduduk yang berkulit putih. Sementara di negara Amerika Serikat terdapat kasus psoriasis sebanyak 150.000 kasus yang ditemukan, hal ini setara dengan 2,2\% dari populasi Amerika Serikat. Sedangkan data prevalensi psoriasis secara nasional di Indonesia masih belum diketahui, namun penelitian yang dilakukan di Rumah Sakit Umum Pusat (RSUP) H. Adam Malik Medan, didapatkan selama periode JanuariDesember 2010 sebanyak 34 pasien $(1.05 \%)$ di antaranya merupakan pasien dengan diagnosis psoriasis. Penelitian yang dilakukan di Poliklinik Penyakit Kulit dan Kelamin RSUP Sanglah Denpasar pada Januari sampai Desember 2009 didapatkan sebanyak 156 kasus baru psoriasis. Penelitian Peggy dkk di RSUP. Prof. Dr. R.D. Kandou Manado periode Januari 2006Desember 2009 didapatkan sebanyak 169 kasus psoriasis yaitu pada tahun 2006 sebanyak 62 kasus, tahun 2007 sebanyak 51 kasus dan tahun 2008 sebanyak 56 kasus. Sedangkan data prevalensi mengenai kasus psoriasis di Rumah Sakit Umum Daerah Zainal Abidin (RSUDZA) Banda Aceh, didapatkan selama periode 1 Desember - 31 Desember 2018 sebanyak 34 pasien psoriasis. Sementara itu, penelitian terbaru mengenai kasus psoriasis yang dilakukan di rumah sakit yang sama didapatkan selama periode 1 Oktober - 31 November 2019 sebanyak 32 pasien psoriasis.

Indonesia sebagai salah satu negara berkembang, belum sepenuhnya mendapat perhatian lebih mengenai penyakit psoriasis, oleh karena itu diperlukan suatu penelitian mengenai profil penderita psoriasis yang dilakukan di RSUD Meuraxa Kota Banda Aceh yang juga merupakan salah satu insitusi kesehatan yang langsung berhubungan dengan masyarakat sekaligus menjadi salah satu rumah sakit rujukan di Provinsi Aceh.

\section{METODE}

Penelitian ini merupakan penelitian deskriptif yang dilakukan secara retrospektif dengan menggunakan data sekunder dari catatan rekam medik lengkap pasien psoriasis di Poli Kulit 
HASIL

Tabel 1. Distribusi Frekuensi dan Presentase Psoriasis Berdasarkan Usia.

\begin{tabular}{ccccc}
\hline Usia & Laki-laki & Perempuan & $\begin{array}{c}\text { Frekuensi } \\
\text { Total }\end{array}$ & $\begin{array}{c}\text { Presentase } \\
\text { total (\%) }\end{array}$ \\
\hline $\mathbf{5 - 1 1}$ & $\mathbf{0}$ & $\mathbf{5}$ & $\mathbf{5}$ & $\mathbf{6 , 1} \%$ \\
$\mathbf{1 2 - 1 6}$ & $\mathbf{2}$ & 4 & $\mathbf{6}$ & $\mathbf{7 , 3} \%$ \\
$\mathbf{1 7 - 2 5}$ & $\mathbf{1}$ & $\mathbf{5}$ & $\mathbf{5}$ & $\mathbf{6 , 1} \%$ \\
$\mathbf{2 6 - 3 5}$ & $\mathbf{8}$ & $\mathbf{1 2}$ & $\mathbf{2 0}$ & $\mathbf{2 4 , 4} \%$ \\
$\mathbf{3 6 - 4 5}$ & $\mathbf{1 0}$ & $\mathbf{6}$ & $\mathbf{1 7}$ & $\mathbf{2 0 , 7} \%$ \\
$\mathbf{4 6 - 5 5}$ & $\mathbf{5}$ & $\mathbf{6}$ & $\mathbf{1 1}$ & $\mathbf{1 3 , 4} \%$ \\
$\mathbf{5 6 - 6 5}$ & $\mathbf{7}$ & $\mathbf{6}$ & $\mathbf{1 3}$ & $\mathbf{1 5 , 9} \%$ \\
$>\mathbf{6 5}$ & $\mathbf{4}$ & $\mathbf{1}$ & $\mathbf{5}$ & $\mathbf{6 , 1} \%$ \\
\hline Total & $\mathbf{3 7}$ & $\mathbf{4 5}$ & $\mathbf{8 2}$ & $\mathbf{1 0 0 , 0} \%$ \\
\hline
\end{tabular}

Berdasarkan Tabel 1, jumlah pasien psoriasis berdasarkan usia yang paling banyak terjadi yaitu pada usia 26-35 tahun berjumlah 20 orang $(24,4 \%)$ dan yang paling sedikit didapatkan pada 3 kelompok usia yaitu pada usia 5-11 tahun, usia 17-25 tahun dan usia $>65$ tahun yang masingmasing berjumlah 5 orang $(6,1 \%)$.

Tabel 2. Distribusi Frekuensi dan Presentase Psoriasis Berdasarkan Jenis Kelamin.

\begin{tabular}{ccc}
\hline JenisKelamin & Frekuensi Total & Presentase $(\%)$ \\
\hline Laki-laki & 37 & $45,1 \%$ \\
Perempuan & 45 & $54,9 \%$ \\
\hline Total & 82 & $100,0 \%$ \\
\hline
\end{tabular}

Berdasarkan Tabel 2, dapat di simpulkan bahwa jumlah pasien psoriasis berdasarkan jenis kelamin yang paling banyak adalah wanita yaitu sebanyak 45 orang $(54,9 \%)$ dan lakilaki sebanyak 37 orang $(45,1 \%)$. Berdasarkan tabel 3, dapat disimpulkan bahwa jumlah pasien psoriasis berdasarkan tipe psoriasis yang paling banyak adalah psoriasis vulgaris sebanyak 68 orang $(82,9 \%)$ dan yang paling sedikit adalah psoriasis guatata sebanyak 14 orang $(17,1 \%)$.

\section{Tabel 3. Distribusi Frekuensi dan Presentase Psoriasis Berdasarkan Tipe} Psoriasis.

\begin{tabular}{lcc}
\hline Tipe Psoriasis & Frekuensi Total & Presentase Total (\%) \\
\hline Psoriasis Vulgaris & 68 & $82,9 \%$ \\
Psoriasis Gutata & 14 & $17,1 \%$ \\
\hline Total & 82 & $100,0 \%$ \\
\hline
\end{tabular}




\section{PEMBaHASAN}

Dari hasil penelitian ini didapatkan bahwa penyakit psoriasis paling banyak terjadi pada usia 26-35 tahun dengan jumlah pasien 20 orang $(24,4 \%)$, terdiri dari 8 laki-laki dan 12 perempuan. Usia 36-45 tahun sebanyak 17 orang $(20,7 \%)$, terdiri dari 10 laki-laki dan 7 perempuan. Usia 56-65 tahun sebanyak 13 orang $(15,9 \%)$, terdiri dari 7 laki-laki dan 6 perempuan. Usia 46-55 tahun sebanyak 11 orang $(13,4 \%)$, terdiri dari 5 laki-laki dan 6 perempuan. Usia $12-16$ tahun sebanyak 6 orang $(7,3 \%)$, terdiri dari 2 laki-laki dan 4 perempuan. Usia >65 tahun, usia 17-25 tahun dan usia 5-11 tahun mempunyai hasil yang sama yaitu sebanyak 5 orang $(6,1 \%)$, pada usia $>65$ tahun terdiri dari 4 lakilaki dan 1 perempuan, kemudian untuk usia 17-25 tahun terdiri dari 1 laki-laki dan 4 perempuan, sedangkan untuk usia 5-11 tahun semuanya terdiri dari perempuan. Jadi dapat disimpulkan pada penelitian ini yang paling banyak mengalami kejadian psoriasis adalah pada usia 26-35 tahun. Seharusnya semakin tua pasien maka semakin banyak kasus tersebut, tetapi angka harapan hidup pada usia > $>5$ tahun di Kota Banda Aceh sangat sedikit yang bisa mencapai usia tersebut, sehingga kasus untuk penyakit psoriasis ini tidak terlalu banyak.

Berdasarkan data yang diperoleh pada penelitian ini didapatkan bahwa pasien berjenis kelamin perempuan lebih banyak terdiagnosis psoriasis dengan jumlah pasien sebanyak 45 orang $(54,9 \%)$, sedangkan pasien dengan jenis kelamin laki-laki sebanyak 37 orang $(45,1 \%)$. Hasil penelitian ini tidak sesuai dengan penelitian yang dilakukan di RSUP Prof. Dr. R. D. Kandou Manado periode Januari 2013 Desember 2015, dimana pada penelitian tersebut yang paling banyak mengalami psoriasis adalah laki-laki. Penelitian ini juga tidak sesuai dengan hasil penelitian yang dilakukan di Poliklinik Kulit Dan Kelamin RSUP Sanglah Denpasar periode Januari 2012 sampai Desember 2014, dimana penyakit psoriasis lebih banyak terjadi pada laki-laki. Hal ini mungkin terjadi karena disebabkan oleh beberapa faktor risiko psoriasis yang lebih sering terjadi pada laki-laki dibandingkan perempuan seperti merokok dan juga komsumsi alkohol. Namun berdasarkan analisis pada hasil penelitian ini, perempuan lebih dominan terkena psoriasis dikarenakan perempuan lebih sering mengalami stres yang emosional yang mana faktor tersebut merupakan salah satu faktor psoriasis. Selain itu, perempuan juga lebih cenderung memperhatikan penampilan mereka sehingga karena adanya penyakit psoriasis yang dideritanya membuat mereka untuk segera berkonsultasi ke dokter karena hal tersebut membuat mereka tidak nyaman dan malu dengan penampilannya.

Menurut data yang diperoleh pada penelitian ini mengenai jenis psoriasis didapatkan bahwa tipe penyakit psoriasis yang paling banyak ditemukan adalah psoriasis vulgaris yaitu sebanyak 68 orang $(82,9 \%)$ dan yang paling sedikit adalah psoriasis gutata sebanyak 14 orang $(17,1 \%)$. Hal ini sesuai dengan hasil penelitian yang dilakukan oleh Michelle $P$, ddk di RSUP Prof. Dr. R. D. Kandou Manado periode Januari 2013 - Desember 2015, bahwa psoriasis vulgaris merupakan tipe yang paling banyak ditemukan yaitu sebanyak 152 orang $(80,85 \%)$ dan psoriasis gutata menempati urutan kedua sebanyak 21 orang $(11,18 \%)$.

Hasil serupa juga didapatkan pada penelitian tahun 2012 oleh Anggelina Moningka, dkk di RSUP Prof. Dr. R. D. Kandou Manado periode Januari - Desember 2012, tipe psoriasis vulgaris merupakan tipe terbanyak yang ditemukan yaitu berjumlah 28 orang $(58,33 \%)$. Hal ini sesuai dengan kepustakaan bahwa psoriasis vulgaris merupakan tipe psoriasis yang paling umum terjadi yaitu sekitar $90 \%$ dibandingkan tipe psoriasis lainnya. 


\section{KESIMPULAN}

Jumlah pasien psoriasis pada penelitian ini yaitu sebanyak 82 pasien. Berdasarkan usia didapatkan kasus terbanyak yaitu pada usia 26-35 tahun dengan jumlah pasien sebanyak 20 orang $(24,4 \%)$, terdiri dari 8 laki-laki dan 12 perempuan. Kasus yang paling sedikit didapatkan pada 3 kelompok usia yaitu pada usia 5-11 tahun, usia 17-25 tahun dan usia >65 tahun yang masing-masing berjumlah 5 orang $(6,1 \%)$. Berdasarkan jenis kelamin didapatkan sebanyak 37 orang berjenis kelamin laki-laki $(45,1 \%)$ dan 45 orang berjenis kelamin perempuan (54,9\%). Dengan demikian, dapat disimpulkan pada penelitian ini perempuan lebih banyak menderita psoriasis dibandingkan laki-laki. Berdasarkan tipe penyakit psoriasis didapatkan kasus terbanyak adalah tipe psoriasis vulgaris yaitu sebanyak 68 orang $(82,9 \%)$ dan kasusyang paling sedikit adalah tipe psoriasis gutata sebanyak 14 orang $(17,1 \%)$. Sedangkan untuk tipe psoriasis lainnya tidak ditemukan dalam penelitian ini.

\section{SARAN}

Bagi pihak Poli Kulit dan Kelamin RSUD Meuraxa Kota Banda Aceh, diharapkan agar melakukan input data status pasien pada rekam medis dengan lebih teratur dan lengkap agar memudahkan peneliti lain yang akan melakukan penelitian berdasarkan rekam medis pasien.

Penulis berharap perbedaan yang terdapat didata buku rekap pasien dengan data rekam medis dapat diminimalisir sehingga tidak menimbulkan kesalahan bagi pihak yang akan mengambil data untuk kepentingan penelitian.

\section{DAFTAR PUSTAKA}

Riandari, F. (2017) 'Sistem Pakar Mendiagnosa Penyakit Kulit Wajah', J Mantik Penusa, 1(2), pp. 85-89.
Dini, A., and Hindayati, M. (2016)

'Sistem Pakar Diagnosa

Penyakit Kulit akibat Infeksi

Jamur (Expert System to

Diagnose of Skin Disease Due to Fungal Infections)', Juita Issn 2086-9398, 4(2), pp. 6777.

Oktaviani, F., Mukaddas, A. and Faustine, I. (2016) ' Drug Use Profile of Patients With Skin Disease at Dermatology and Venereology Polyclinic in Anutapura General Hospital Palu', Galen J Pharm, 2(3), pp. 38-42.

Krisnarto, E., Novitasari, A. and Auliarahma, D. M. 'Faktor Prediktor Kualitas Hidup Pasien Psoriasis : Studi Cross Sectional Quality of Life Sectional Study Predictor Factors of Psoriasis Patients', Jurnal Unimus, pp. 049.

Madhur, M. (2019) 'Psoriasis', Practice Essentials, 9(14), doi: 1943419.

Astrid, C., Putranti, I. O., and Purwanti, K. D., dkk. (2018) 'Perbedaan Tingkat Keparahan Psoriasis pada Pasien Psoriasis dengan dan tanpa Fokal Infeksi Difference of Psoriasis Area Severity Index Between', Mandala Heal a Sci J, 11(2), pp. 80-94. doi: 10.20884/1. Mandala.11.2.944.

Moningka, A., Kandou, R. T., dan Niode, N. J. (2015) 'Profil Psoriasis di Poliklinik Kulit dan Kelamin RSUP Prof. Dr. R. D. Kandou Manado Periode Januari-Desember 2012', eClinic, 3(2), pp. 2-6. doi: 10.35790/ecl.3.2.2015.8384.

Menaldi, S. W., Linuwlh, S., and Bramono, K. I. W. (2017) I/mu Penyakit kulit dan Kelamin. Edisi ke-7. doi: 9789794968529.

Eroschenko, V. P. (2015) Atlas Histologi di Fiore dengan Koleransi Fungsional. doi: 9789790445932. 
Boham, M. P., Suling, P. L., and Pandaleke, H. E. J. (2016) 'Profil Psoriasis di Poliklinik Kulit dan Kelamin RSUP Prof. Dr. R. D. Kandou Manado Periode Januari 2013Desember 2015', e-Clinic, 4(2). doi: 10.35790/ecl.4.2.2016.14459.

WHO. (2016) 'Global Report on Psoriasis', Glob Rep Psoriasis, pp. 1-26.

Aprilliana, K. F. dan Mutiara, H. (2017) 'Psoriasis Vulgaris pada Lakilaki 46 Tahun (Psoriasis Vulgaris in 46 Years Old Male)', 4, pp. 160-166.

Damayanti, K. D. P. (2018) 'Profil Psoriasis Vulgaris di RSUD Dr. Soetomo Surabaya : Studi Retropektif (Psoriasis Vulgaris : A Retrospective Study)', IImu Kesehatan Kulit dan Kelamin, 30(3), pp. 248-254.

Perdoski. (2017) Panduan Praktek Klinis bagi Dokter Spesialis Kulit dan Kelamin di Indonesia.Vol 2, doi: 10.1021/jo900140t.

Kim, W. B., Jerome, D. and Yeung, J. (2017) 'Diagnosis and Management of Psoriasis', Can Fam Physician, 63(4), pp. 278285.

Dewa, A. P. and Novita, D. (2018) 'Insiden dan Profil Psoriasis di Poliklinik Kulit dan Kelamin Rumah Sakit Umum Pusat Sanglah Denpasar Periode anuari 2012- Desember 2014', E-Jurnal Med, 7(9), pp. 1-7.

Utami, D. (2018) 'Hubungan Skala Stres dan Kadar Kortisol Serum dengan Skor Psoriasis Area and Severity Index (PASI) pada Pasien Psoriasis Vulgaris'. 